\title{
転移 RNA の生物学的变動
}

\author{
石田 寅 夫 \\ Torao ISHIDA \\ 旭化成工業株式会社技術研究所
}

転移 RNA (tRNA) は, 蛋白合成の際に伝達 RNA (mRNA) の遺伝暗合 (genetic code) を蛋白のアミノ酸 配列に翻訳 (translation)する重要な生体高分子である. 蛋白合成のパターンが激变する細胞の分化や発達, ウイ ルス感染, および癌化などの際に, この tRNA の生物 学的変動（同じアミノ酸を受容する tRNA 間の量比の 変化, 既存の tRNA の修飾, 扤よび新しいtRNAの 合成）がしばしば認められる. しかし, サップレッショ ン（変異により哑失した特定蛋白の合成能力が, 他の遺 伝子の変異により回復する）が，変異によって読まれな くなった code を読むことのできる tRNA の出現によ ることが明らかにされた以外には, 蛋白合成の調節機構 に打ける tRNA の役割はまだ不明である.

ここでは, tRNAの生物学的変動と蛋白合成の調節と の関係について考えてみたい，最初に必要な範囲で蛋白 合成機構について触れ, 次に tRNA の変動の化学的根 拠について考觉，最後に筆者の仕事を含めた意味でのプ リンストン大学の Dr. N. Sueoka 研究室のデータを中心 にして, tRNA の変動に関する研究を紹介したい。な 招, Sueoka らのメチル化アルブミン珪藻土(MAK) カラ ムクロマトグラフィーは, 2 つの tRNA 標品の直接比 較を小規模で可能にし, Kelmers らの逆相カラムクロ マトグラフィーは，さらにその分離度を高めた．さらに， 筆者らの tRNA のアミノ酸付着末端付近のヌクレオチ ド配列の違いを調べる方法により，この tRNA の変動 が新しい tRNA の合成によるのかぞうかを小規模で調 査することが可能になり，tRNA の変動が追いやすくな った. 編集方針に従って個々の文献は省略するので，比 較的新しい文献も載っている Söll の蛋白合成に関する
総説(1) と, Sueoka の tRNA と細胞分化に関する総 説 (2)を参考にされたい。

\section{1． 蛋白合成機構}

蛋白の合成機構は非常に複雑であるが，活性化段階， 開始段階, 伸長段階, 終了段階の 4 つに分けて考兄ると わかりやすい，な拉，この機構は微生物に怙いて明らか にされたことをもとにして書かれていることを抗ことわ りする.

\section{1）活性化段階}

アミノアシル tRNA (AA-tRNA) は, 一般には, 特 定のアミノアシル tRNA 合成酵素により特定のアミノ 酸が tRNA に付加されてつくられる. 開始段階に関与 するホルミルメチオニル tRNA(f.Met-tRNA $\mathrm{f}_{\mathrm{f}}$ ) の場合 はすこし特殊である.すなわち, mRNA の最初に存在 する code AUG とのみ反応して, 途中に存在するこの code とは反応しない特殊な tRNA $\left(\mathrm{tRNA}_{\mathrm{f}}\right)$ に, メチ オニル tRNA 合成酵素によりメチオニンが付加された 後, この付加されたメチオニンの $\alpha$ イミノ基がホルミ ル化されて f.Met-tRNA

\section{2）開始段階}

開始因子* $\mathrm{F}_{3}$ と $\mathrm{F}_{1}$ の助けで, $30 \mathrm{~S}$ 粒子(リボゾー ムの一構成単位）と結合した mRNA の開始 code であ

* 粗リボゾームを塩化アソモニウムで洗浄することにより, リボゾームから分離される蛋白質状の物質で, DEAE 七 ルロースクロマトグラフィーで 3 物質 $\left(F_{1}, F_{2}, F_{3}\right)$ に分 けられる. $\mathrm{Mg}^{2+}$ が低濃度のときは，これらの物質を添加 しないかぎり純化したリボゾームは活性を示さない. 

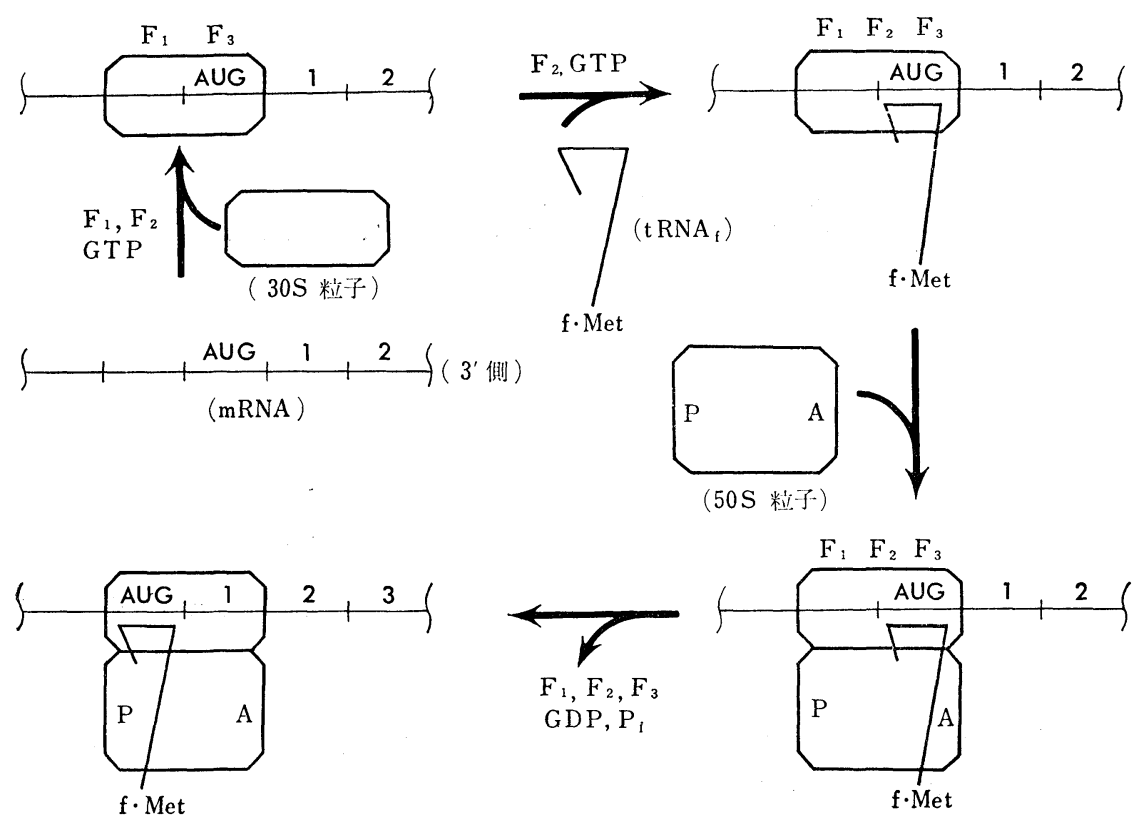

図 1 開 始 段

万 AUG 上に, もう 1 つの開始因子 $F_{2}$ の助けで $f$. Met-tRNA f が結合する. これに $50 \mathrm{~S}$ 粒子（リボゾー ムのもら一方の構成単位) が付加されて, 70 S リ゙ジ 一ム, mRNA, 特よび f.Met-tRNA の 開始複合物が できる、リボゾームが, mRNA 上を開始 code からそ の $3^{\prime}$ 側に隣接する code にまでずれるに応じて, 最初 リボゾームの部位 $\mathrm{A}$ (アミノアシル tRNA が結合する 部位) に存在した $\mathrm{f} \cdot \mathrm{Met}-\mathrm{tRNA}$ f がもう一方の部位 $\mathrm{P}$ (ペプチジル tRNA が結合する部位) に転移して, 部位 A があく（図 1).

\section{3）伸長段階}

このあいた部位 Aに, 二番目の code に対応したアミ ノアシル tRNA が，伸長因子* Tu と Ts（または $\mathrm{S}_{3}$ と $\mathrm{S}_{1}$ ) の助けで結合する. 次に, ペプチジル転移酵素 の助けで部位Pに存在する f.Met-tRNA 基のカルボキシル基が, $\mathrm{tRNA}_{\mathrm{f}}$ からはなれて, 部位 $\mathrm{A}$ に付加しているこの AA-tRNA の AA 残基の $\alpha-ア ミ$ ノ基と結合して，ペプチド結合をつくる.このとき， $\mathrm{tRNA}_{\mathrm{f}}$ は部位 $\mathrm{P}$ から遊離して部位 $\mathrm{P}$ があく．このよう にしてつくられたホルミルメチオニルアミノアシル tRNA（f·Met-AA-tRNA ） は, も5 1 つの伸長因子 G

* 高速上清区分に含まれる蛋白質. T 因子は熱安定な物質 (Ts) と不安定な物質（Tu）からなり，tRNA をリボゾ 一ムに結合させる酵素. G因子はペプチジル tRNA を部 位 A から部位 P に転位させる酵素.
（または $\mathrm{S}_{2}$ ）の助けで部位 $\mathrm{A}$ から部位 $\mathrm{P}$ に転移する. このよらにして, 次々と $\mathrm{mRNA}$ 中の code の配列に 応じてアミノアシル tRNA が部位 A に結合した後, 部 位 $\mathrm{P}$ に存在するペプチジル tRNA のペプチジル残基が この部位 $\mathrm{A}$ のアミノアシル tRNA に移されてペプチド 鎖が伸長し, このペプチドが1つ伸長したペプチジル tRNA は部位 A から部位 P に転移する（図 2).

\section{4）終了段階}

最後に, 終了 code に対応して遊離因子 $\mathrm{R}$ (UAA ま たは UAG に対し $\mathrm{R}_{1}$, UAA または UGA に対し $\mathrm{R}_{2}$ ) が部位 A に結合すると, 部位 $\mathrm{P}$ に存在していたポリペ プチジル tRNA のポリペプチドが遊離される. も5 1 つの遊離因子 $\mathrm{S}$ は, 遊離因子 $\mathrm{R}$ のリボゾームへの結合 を促進する.ポリペプチドが遊離されると同時に, リボ ゾーム, mRNA 特よび tRNA の複合物は各構成物に 分離されて蛋白の合成が完了する.

以上の説明で明らかなごとく, tRNA には, 対応した アミノアシル tRNA 合成酵素を認識して対応するアミ ノ酸を受容する機能と, 対応する code に反応してリボ ゾームと結合する機能と, 付加したアミノ酸をペプチド 鎖中に取込ませる機能とがあり, これらの機能を別々に 測定することは可能である.これらの機能から, tRNA には酵素を認識する部位, アミノ酸の付着する部位（ア ミノ酸付着末端アデノシン), リボゾームと結合する部位, 


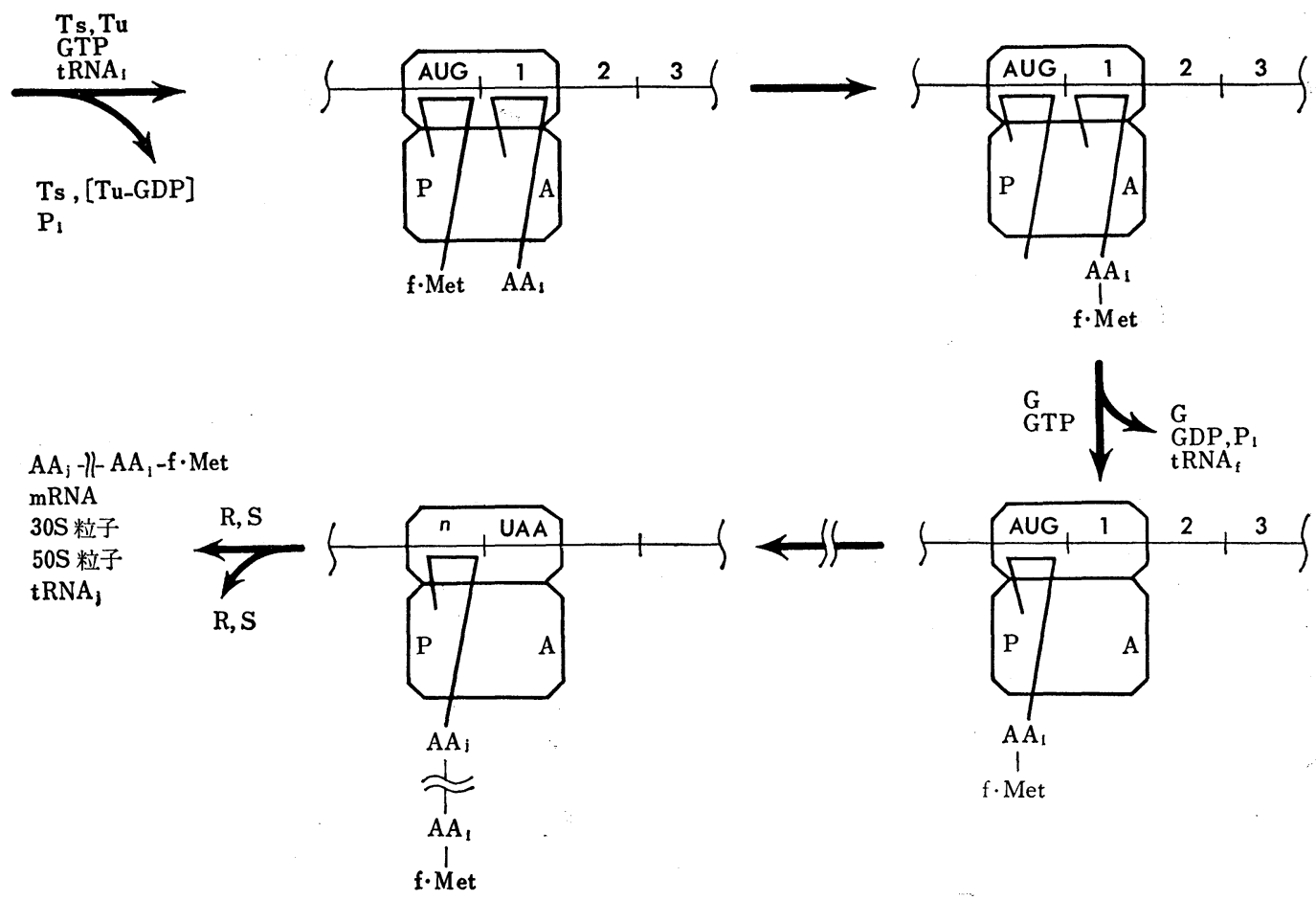

図 2 伸長段階および終了段階の模式図

code と結合する部位 (anticodon) が考学られるが，ア ミノ酸付着部位と anticodon 以外の部位は tRNA の ぞこにあるか不明である（図 3 ）.

\section{2. 翻訳レベルにおける蛋白合成の調節機構}

蛋白合成の調節には，すべての蛋白合成を中止させる 巨視的調節 (macroregulation) と, 特定の蛋白群のみ を誘導または抑制する微視的調節 (microregulation) が ある、調節を受けるレベルとして， mRNA の合成を調 節する転写レベル (transcriptional level) と, mRNA の情報を解読して蛋白をつくる翻訳レベル (translational level) が考えられるが，ここでは後者のみについて 触れる. 翻訳レベルでの蛋白合成の調節機構としては, 特殊 code の存在, 開始因子, 伸長因子, 遊離因子, ア ミノアシル tRNA 合成酵素などの変動のほかに, tRNA の変動による調節も考えられる。

\section{1） tRNA の変動の化学的根拠}

tRNA の変動による調節の可能性を列記してみると, (1) 分子内塩基対または塩基積重の再整列による高次

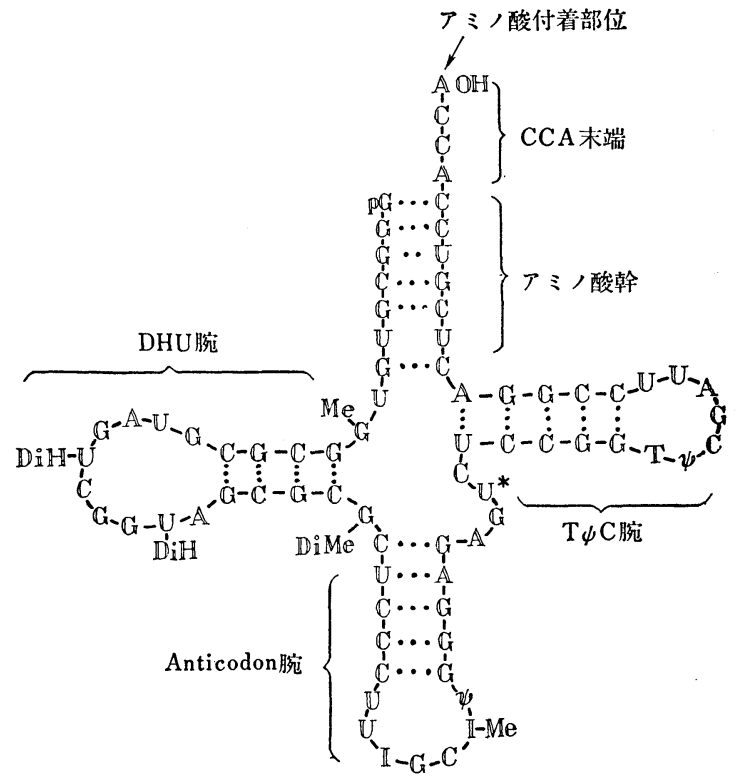

図 3 酵母アラニン tRNA のクローバー葉モデル R. W. Holley, J.Apgar, G. A. Everett, J. T. Madison, M. Marquisee, S. H. Merrill, J.R. Penswick and A. Zamir : Science, 147, 1462 (1965). 
構造の変換による不活化または活性 化（筆者らの大腸菌トリプトファン tRNA, Fresco らの酵母ロイシン tRNA).

(2) アデニル酸ピロホスホリラー ゼによる3'-末端アデノシン，また は CCA (図 3) の解離拉よび付加 による, アミノ酸受容能の不活化お よび活性化（Glisin らの無精卵お よび受精卵の tRNA の比較, ただ 乙無精卵の tRNA も受容能がある).

(3) メチル化酵素によるポリヌク レオチドレベルで, tRNA 中の特定 の位置にある特定の塩基のメチル化 による活性化 (Peterkofsky らの大 腸菌のメチル不足ロイシン tRNA, Littauer らのフェニルアラニン tRNA).

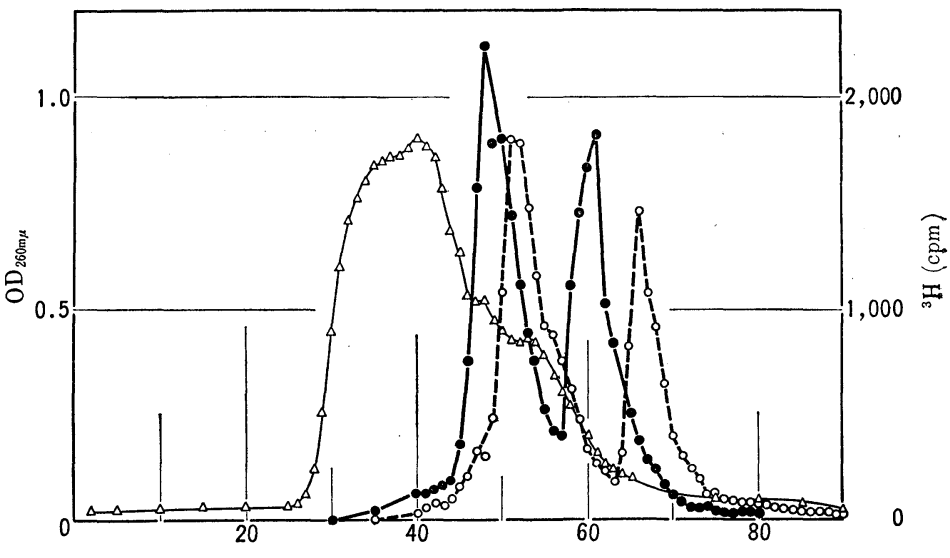

Fraction number

図 4 トリプトファン tRNA とトリプトファニル tRNA の活性型と 不活型の MAK カラム上での比較 ${ }^{(3)}$

\begin{tabular}{|c|c|}
\hline$\bullet \longrightarrow$ & $\begin{array}{l}\text { トリプトファン tRNA の活性型（前のピーク）と } \\
\text { 不活型(後のピーク) }\end{array}$ \\
\hline $0---0$ & $\begin{array}{l}\text { トリプトファニル tRNA の活性型（前のピーク）と } \\
\text { 不活型(後のピーク) }\end{array}$ \\
\hline$\Delta-\Delta$ & 全 $t R N A$ \\
\hline
\end{tabular}

(4) 特定の tRNA に含まれる4-チオウラシルな ぞ, チオール基の酸化還元による不活化拈よび活性化 (Jones らの大腸菌 tRNA, Doi らの枯草菌リジン tRNA).

(5) Anticodon 部位の $3^{\prime}$ 側の隣りに位置するアデ ノシンの 2-メチルチオ- $\mathrm{N}^{6}-$ イソペンテニル化，または $\mathrm{N}^{6}$-イソペンテニル化による活性化 (Russell らの大腸 菌サプレッサーチロシン tRNA, Hall らの酵母セリン tRNA).

（6 特定のアミノ酸を受容する tRNA のらちで, 特 定の code に対応するものの存在量が少なすぎることに よる蛋白合成の律速 (Anderson らの AGA 扣よび AGG に対応する大腸菌アルギニン tRNA).

(7) リボヌクレアーゼによる特定 tRNA の特定部位 の切断による不活化 (Sueoka らの $\mathrm{T}_{2}$ ファージ感染後 の大腸菌のロイシン $\left.\mathrm{tRNA}_{1}\right)$.

(8) 新しい系に特異的な tRNAの新たな合成 (SubakSharpe らのヘルペスウイルスのアルギニン tRNA, Weiss らの $\mathrm{T}_{4}$ ファージのロイシン tRNA).

(9) 特殊な code に対応した特殊な tRNA の結合に よる, mRNA のリボゾームからの解離に伴ら蛋白合成 の中止（例なし, 遊離因子 $\mathrm{R}$ 状の tRNA を予想).

(10) 新しく合成された阻害剂による tRNA の不活化 (Hung らの $Q_{\beta}$ ファージ感染後の大腸菌のプロリン tRNA).

(11) 転写レベルの調節ではあるが, tRNA のアシル化

表 1 リボソームに結合したトリプトファニル tRNA の量 ${ }^{(4)}$

\begin{tabular}{|c|c|c|c|}
\hline \multicolumn{2}{|c|}{ ヌクレオチド $\left(\mathrm{A}_{260}\right.$ 単位 $)$} & \multicolumn{2}{|c|}{ 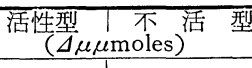 } \\
\hline poly UG & $(0.35)$ & 2.47 & -0.21 \\
\hline UpGpG & $(0.19)$ & 0.62 & -0.22 \\
\hline $\mathrm{UpGpA}$ & $(0.20)$ & 0.39 & -0.09 \\
\hline $\mathrm{CpGpG}$ & $(0.21)$ & 0.09 & -0.10 \\
\hline $\mathrm{ApGpG}$ & $(0.20)$ & 0.08 & -0.15 \\
\hline poly $\mathrm{AC}$ & $(0.35)$ & & 1.31 \\
\hline poly UC & $(0.35)$ & & 0.16 \\
\hline poly $\mathrm{CG}$ & $(0.35)$ & & -0.03 \\
\hline poly AG & $(0.36)$ & & -0.07 \\
\hline poly UI & $(0.38)$ & & -0.37 \\
\hline poly UG & $(0.37)$ & & -0.25 \\
\hline
\end{tabular}

の度合による mRNA 合成の調節（Roth らのサルモネ ラ菌のヒスチジン tRNA).

などが考学られる、ただし，ここに引用した例の多くは in vitro で確認されただけであるから，そのらちのどれ が実際の調節に関与しているかはこれからの問題である。

\section{2）大腸 菌}

筆者らは, in vitro で大腸菌のトリプトファン tRNA の高次構造の再整列による不活化と活性化について明ら かにした. 大腸菌のトリプトファンを運搬する tRNA は, トリプトファンを付加した状態（トリプトファニル tRNA）拉よび付加していない状態（トリプトファン tRNA) のいずれでも, 活性型 (Form I) と不活型 (Form II) の 2 つ高次構造をとりらる.これは, 


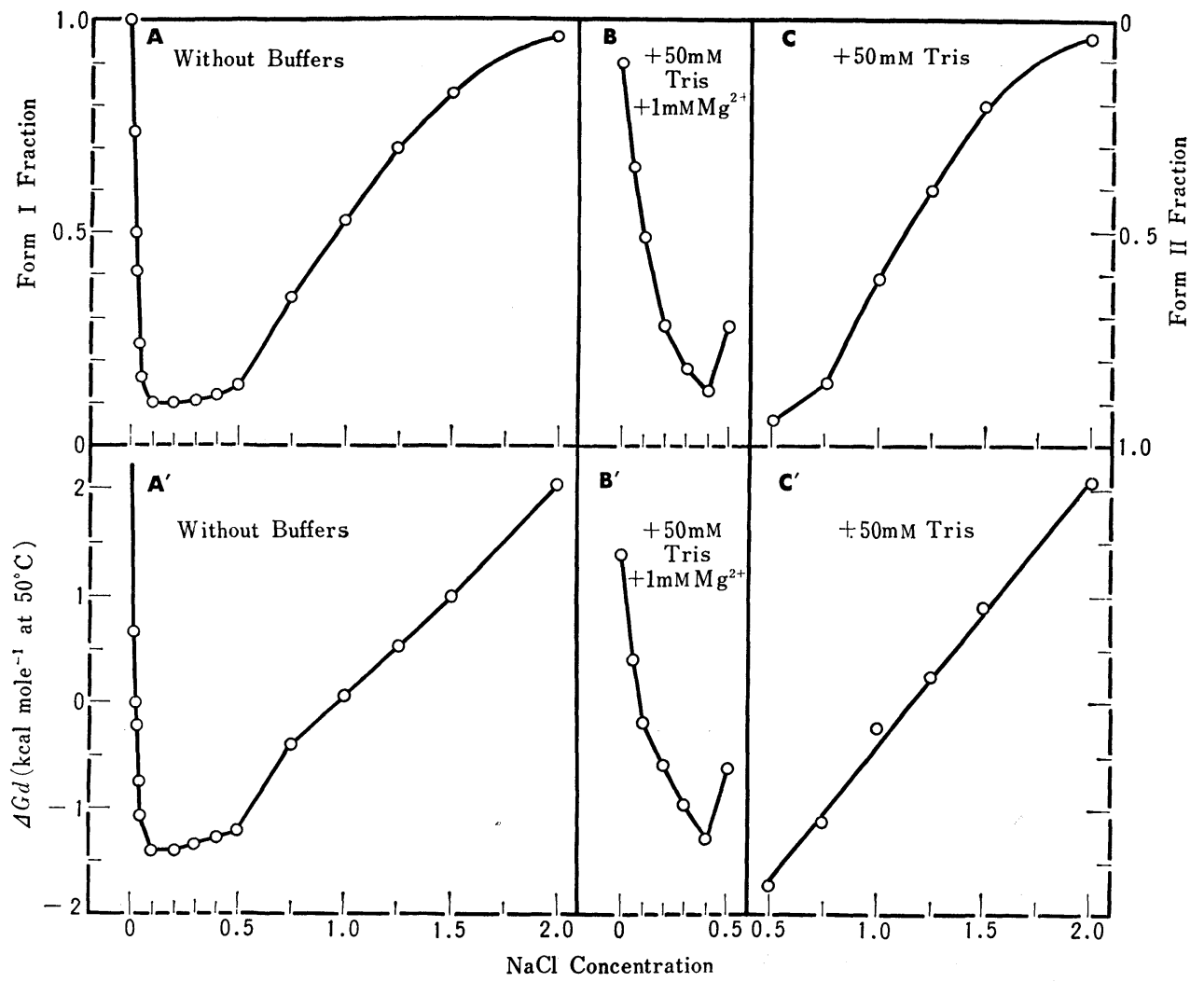

図 5 活性型 (Form I）に対する食塩濃度の影響 (5)

MAK カラムからは活性型, アシル化活性型, 不活型お よびアシル化不活型の順で溶離される（図 4). 活性型 はトリプトファニル tRNA 合成酵素によりトリプトフ アニル化するのに対し，不活型はトリプトファンを受容 しない，活性型は code UGG または poly UG 下でのみ リボゾームと結合するが，不活型はリボリ゙ームの存在に かかわらず poly AC とのみ結合する（表 1)．活性型 が poly UG によるペプチド鎖合成に関与するのに対し， 不活型に付着するトリプトファンは poly UG および poly AC のいずれの存在下でもぺプチド鎖中に取込ま れない。

不活型には, クロバー葉モデル（図 3）の“アミノ酸 幹”, “anticodon 腕”, “ $\mathrm{T} \psi \mathrm{C}$ 腕”などに相当する部位 は存在するが, “DHU 腕”相当部位はない（未発表, N.Sueoka との共同研究). 両型の分子吸光度, 沈降速 度, RNA 分解酵素 $\mathrm{T}_{1}$ の感受性, エントロピー, エン タルピーの差などから，両型の相互変換は，この “DHU 幹”相当部位の塩基対の形成と破壞に伴う三次構造の変 換によると思われる。この相互変換は可逆的一次反応で あり，低温では両型とも準安定で共存するが，温度上㫒 に伴いその変換が加速される.

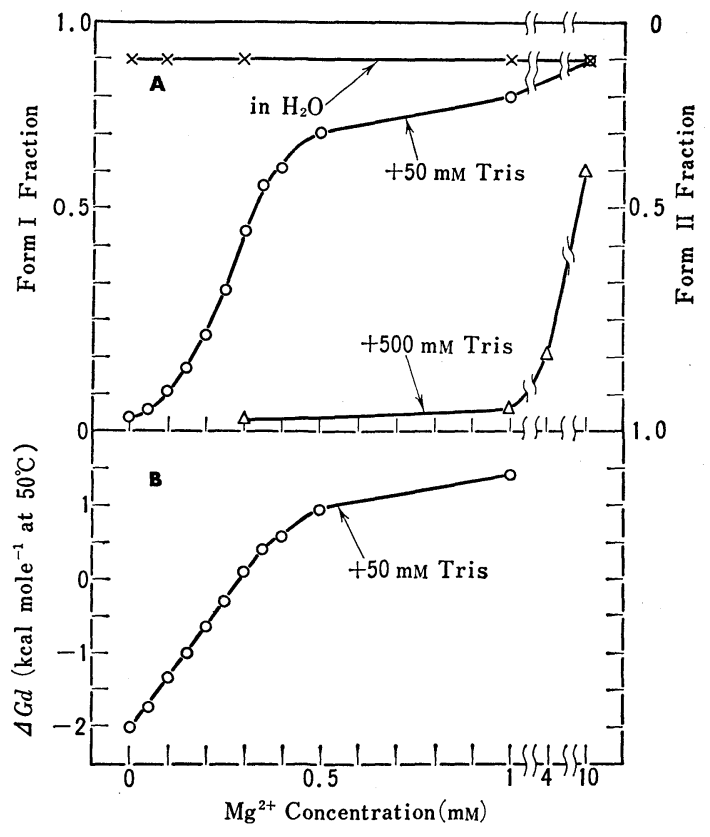

図 6 活性型(Form I) に対する $\mathbf{M g}^{2+}$ 濃度の影響(5) 


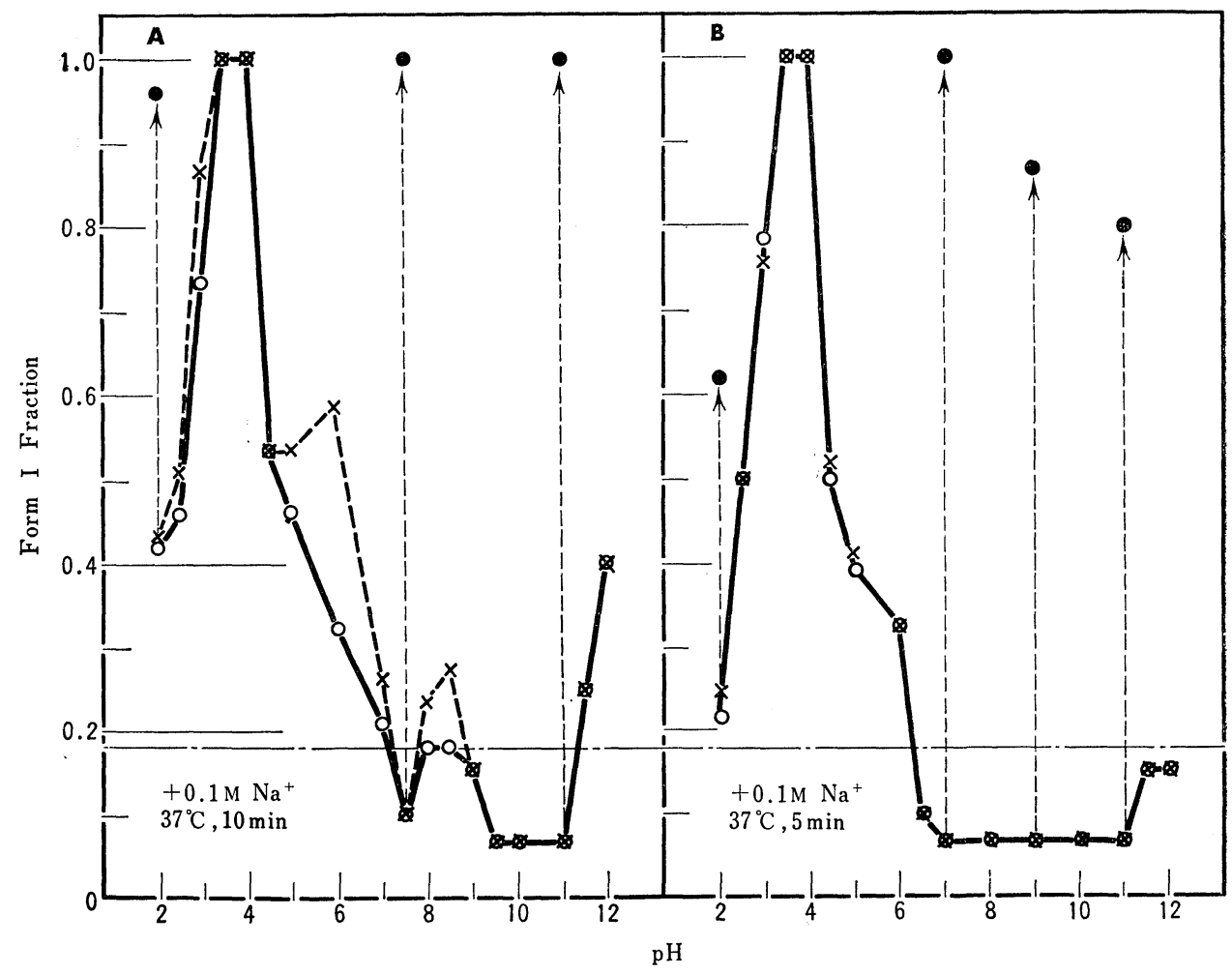

图 7 活性型（Form I）に対する pH の影響(5)

陽イオン濃度の増加および温度減少に伴って, 活性型 の自由エネルギー变化量は增加し, 不活型のそれは減少 する. 不活型は活性型より高水準のエンタルピー招よび エントロピーを有するが, この相互変換中に両型のいず れよりも高水準のエンタルピー牤よびェントロピーを有 する遷移状態を通過する，1洒陽イオンは高濃度では活 性型を形成するが，低濃度では不活型を形成し，2 価陽 イオンによる活性型の形成を拮抗的に阻害する（図 5,

图 6). 酸性中扣よび水中では活性型として測定される (図 7). $\mathrm{Mg}^{2+}$ は必ずしも活性型㹸必要でないことが MAK カラムを用いて証明される（図 8). 生体内の $\mathrm{Mg}^{2+}$ 濃度が不均一で, 局所的に $10^{-4} \mathrm{M}$ である場合る あれば，そこでは不活型の存在も可能のはずである. tRNA の不活型による細胞の代謝調節の in vivo での 観察はなされていないが, むしあるならば非常に能率の よい代謝調節機構である.

\section{3）枯草 菌}

枯草菌は胞子を形成しうるので, 細胞分化の単純な系 として興味深い. リジンー (Lazzarini), セリンー, バリ ンー (Doi ら), チロシンー (Sueoka ら) tRNA の変動が報 告されている.たとえば, Sueokaらによれば, Penas- say 溶液で枯草菌を堌殖させると, 対数増殖期にチロシ ン tRNA (Tyr I) だけが存在し, 定常期が近づくに つれて Tyr I が減少し, む5 1 つのチロシン tRNA (Tyr II) が現われてくる. 定常期ではほとんど Tyr II のみが存在する.このチロシン tRNA の変動は培養液 に依存し, 含アミノ酸最小培地では, 増殖期括よび定常 期のいずれにもこの 2 種のチロシン tRNA が共存す る. 両者のアミノ酸の受容, code 反応, アミノ酸の取 込みなどの機能は同じであり, in vivo での意義は不明 である.

\section{4）ウイルス感染}

ウイルスが細胞に感染すると, 細胞の代謝からウイル スの子孫をつくる代謝に劇的に切りかわる，その上，感 染中のウイルスの増殖過程に和いても, 前期から後期へ の蛋白合成の切りかえが起こる.なお，この前期から後 期への切りかえは転写レベルで起こるのでここでは触れ ない.

Sueoka らによると, 大腸菌のロイシン tRNA の 1 つ (Leu 1) が $\mathrm{T}_{2}$ ファージ感染直後（1２分）に誘導 されるヌクレアーゼにより、リボゾーム上で切れる.こ の刻み目をつけられた tRNA は，水素結合でつながっ 


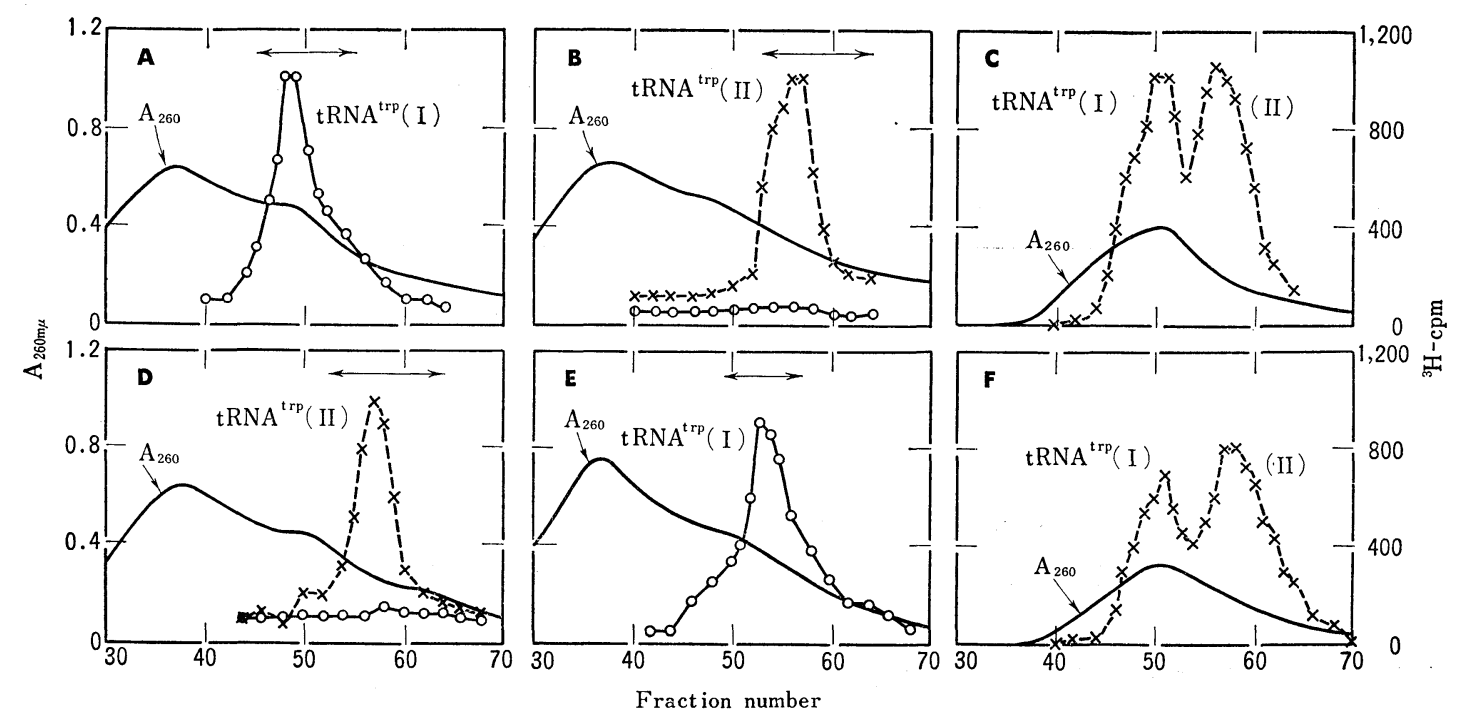

図 8 MAK カラムクロマトグラフィーによる活性型 (Form I ) の $\mathbf{M g}^{2+}$ 必要性の否定 $^{(6)}$ 透析後, $1 \mathrm{~mm}$ EDTA を含んだ $0.1 \mathrm{M}$ Tris 緩衝液 ( $\mathrm{pH} 7.5)$ に移し(A), $50^{\circ} \mathrm{C}$ で 10 分間加熱して (B), 冷却後 $1 \mathrm{~mm}$ EDTA と $2 \mathrm{M} \mathrm{NaCl}$ を含む $0.1 \mathrm{M}$ Tris 緩衝液 ( $\mathrm{pH} 7.5)$ に移し(D), $50^{\circ} \mathrm{C}$ で 10 分間加熱した（E）tRNA の MAK カラムクロマトグラフィー. (C) は（A）および（B）の，(F)は（D）および（E）のトリプトファン tRNA 部分の再クロマトグラフィー).

ていてロイシン受容能をまだ有するが, いったんロイシ ル tRNA 合成酵素によりロイシンを付加すると, 半分 子ずつに分離され，もはやロイシン受容能はない。この 半分子はリボゾームとの結合能, ロイシンの蛋白への取 込久能はないが, poly UG と特異的に結合する. $\mathrm{T}_{2}$ フ ァージ感染前と感染 8 分後の 5 種のロイシン tRNA の code の性質に変化はなく, Leu, CUG; $\mathrm{Leu}_{2}, \mathrm{CUU}$, CUC; $\mathrm{Leu}_{3}, \mathrm{CUA}, \mathrm{CUG} ; \mathrm{Leu}_{4}, \mathrm{UUG}$; Leu 5 , UUG で あった. MAK カラムの溶離度は $\mathrm{Leu}_{1 \sim 3}$ については変 化なく, Leu $_{4}$ 抢よび $\mathrm{Leu}_{5}$ ほ感染前後で異なっていた.

Weiss らは, $\mathrm{T}_{4}$ ファージ感染後に出現するロイシン tRNA は $\mathrm{T}_{4}$ DNA とのみ混成 (hybridization) し, $\mathrm{T}_{4}$ 遺伝子によって新たに合成された tRNA であるこ とを示した.すなおち, ファージ感染により, 宿主の特 定の tRNA を切断して不活化して宿主の蛋白合成を中 止させ,ファージに特異的な tRNA を新たに合成させ て，それを用いてウイルスの蛋白合成を進行させる翻訳 レベルでの調節の可能性が示された. 一方, Steitzら は, 大腸菌に $\mathrm{T}_{4}$ ファージが感染すると, リボท゙ームは $\mathrm{R}_{17}$ ファージ RNA の外套蛋白掞よび合成醉素開始部位 との結合能を失い，A蛋白開始部位とのみ結合すること， 扣よびこのリボゾームの特定 mRNA との結合能の衰失 が, 開始複合物の形成を助ける開始因子の変化によるこ とを示した. すなわち, mRNA のリボท゙ームへの結合 の段階で, 宿主の蛋白合成からファージの蛋白合成への
切りかえが起こる可能性もある.

動物ウイルスについても，ウイルス感染による異なる tRNA の合成が報告されている. Subak-Sharpe らに よれば, ヘルペス DNA は感染後の tRNA とハイブリ ッドをつくり，感染前の tRNA とはハイブリッドをつ くらない. MAK カラム上のアルギニン tRNA のパタ 一ンは感染前後で異なり，筆者らの方法により，感染前 後でアルギニン tRNA の一次構造の異なることを示し た.

\section{5）異種間の比較}

異種間の tRNA の比較により, tRNA レベルの進化 を見ることができる、筆者らは，バクテリアのトリプト ファン tRNA について類縁関係を調べた（未発表，N. Sueoka との共同研究). 全 tRNA 飞比し, トリプトフ フン tRNA は Bacillus 属菌, Seratia 属菌では早く, Micrococcus 属菌では同時飞, Salmonella 属菌, Shigaella 属菌, Aerobacter 属菌拉よび E. coli では遅く 溶離される. Pseudomonas 属菌では, 全 tRNA に比し 早く溶離されるものと遅く溶離されるものの 2 種存在す る. このように，バクテリア間でトリプトファンtRNA の構造が異なるにもかかわらず，いずれのトリプトファ ン tRNA も大腸菌のアミノアンル tRNA 合成醅素に よってトリプトファニル化し, poly UG の存在下での み大腸菌リボゾームと結合しこのトリプトファニル

Vol. 8 , No. 9 


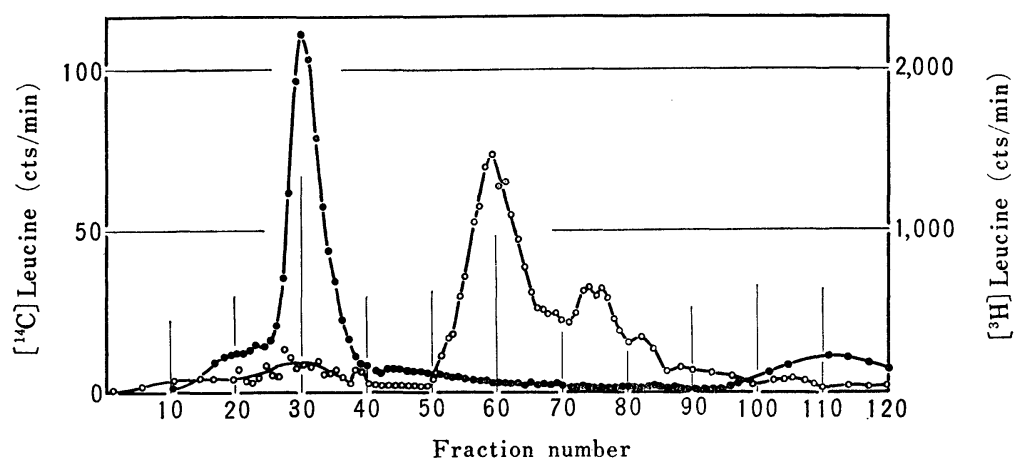

図 9 大腸菌の ${ }^{3} \mathrm{H}$-ロイシル tRNA と酵母の ${ }^{14} \mathrm{C}$-ロイシル tRNA とのリボ 核酸分解酵素 $\mathbf{T}_{1}$ 分解物の DEAE セルロースクロマトグラフィー(7)

-— ${ }^{3} \mathrm{H}$

tRNA からトリプトファンが蛋白の中に取込まれる．す なわち，機能部位は類似しているものと考えられる.

しかし，大腸菌と酵母間では機能部位の類似性もうす くなる.たとえば，酵母 tRNA は大腸菌の酵素によっ ては一部の tRNA しかロイシンを受容しない.かつ， ロイシン tRNA のアミノ酸付着末端付近の構造は大腸 菌と酵母で異なる（図 9)．類縁関係の遠いものほど機 能部位の構造も異なり, 生物の進化について, その生物 系に適した tRNA が生き残っているようである.

\section{6）異組織間の比較}

酵母（Wintersberger)，ノイロスポア (Barnett ら), テトラヒメナ (Suyama), ラット肝 (Buck ら, Lietman) のミトコンドリアに存在する tRNA は, 細胞質 由来の tRNA と異なり,むしろバクテリアの tRNA に近いと思われる.

Holland らによれば, 同種異組織执よび器官の tRNA の構造は一般に似て括り，差の存在するほうが例外的で ある、すなわち，異組織または器官の細胞で合成される 異なる蛋白は転写レベルで調節されているものと考えら れる.

\section{7) 分 化}

多細胞系の各成長期に括ける tRNA の変動の報告は 多くあるが，tRNA が分化に関与することを直接示し たのは, Ilan らのゴミムシダマシのさなぎに関する実 験である.ゴミムシダマシのさなぎの無細胞抽出物中で のチロシンとロイシンの蛋白への取込みの比は，成虫に なるにつれて上年し 10 倍になる，これは，成虫のクチ クラ蛋白が高濃度にチロシンを含んでいるからと思われ る. 第 1 日目のさなぎのリボゾームと mRNA の複合体 $\bigcirc-\bigcirc{ }^{14} \mathrm{C}$

を用いても, 成虫になる最後の段階の tRNA と酵素を 含む上清区分とを用いるかぎり，チロシンとロイシンの 蛋白への取込名の比は高く, できた蛋白のトリプシン分 解物は成虫の上皮蛋白のそれと似ている，すなわち，第 1 日目のさなぎはすでに成虫のクチクラ蛋白のための mRNA を持っているけれども，その mRNA の情報を 蛋白に翻訳させるためには後期のさなぎの tRNA と酵 素とが必要である.

この後期のさなぎには，新しいロイシン tRNA と口 イシル tRNA 合成酵素とが合成されることが示された， ゴミムシダマシの幼虫ホルモンを作用させると, 日数を 経てもこの新しいロイシン tRNA とその酵素は出現せ ず，かつこのホルモンを作用させた昆虫の上清区分を用 いるかぎり，いかなる時期のリボゾームと mRNA の 複合体を用いても, チロシンとロイシンの取込み量の比 は低い、すなわち, tRNA による分化の調節と, ホルモ ンによる tRNA の合成の抑制が示された.

\section{8）癌化}

Holland らによれば, 正常な繊維素細胞には繊維素細 胞型チロシン tRNA，正常な上皮細胞には上皮細胞型 チロシン tRNA のみがそれぞれ存在するが, 癌細胞の らちで HeLa 細胞, Ehrlich 腹水腫瘍, および adeno 7 型によりトランスホームされたハムスター細胞には, 両者が存在する.

そのほか, 多くの細胞系について, 癌化に伴い $\mathrm{tRNA}$ の変わることがカラムクロマトグラフィーのパターンの 変化から示されているが, この tRNA の変動が tRNA の修飾によるのか，新たな tRNA の出現によるのかは 明らかにされていない報告が多い、また，この tRNA の変動が癌化の原因か結果かが不明であり, もら少しつ 
っこんだ研究が望まれる。

Axel らによれば, ラット肝には 2 種のロイシン tRNA があり，一方は poly UC に反応し，他方は poly UG に反応する. エチオニンで 1 カ月ラットを飼 ら上肝 tRNA がエチル化されるが，このエチル化され たロイシン tRNA は poly UC としか反応しない、エ チオニンによる飼育を続けて発癌させ，この肝癌を移植 してェチオニンを含まない慨で飼育したラットのロイシ ン tRNA は正常型であった. すなわち，この tRNA の変動が肝癌の開始に関与しているかもしれないが, 癌 の維持には不必要である.

なお，正常細胞と癌細胞の比較の際に注意しなければ ならないことは, Yang らの報告のごとく, 同じ癌細胞 でも in vitro 培養と in vivo 培養で tRNA の変動が 認められることである. 癌化に本質的な変動であるの か，培養条件の違いによる変動であるのか，区別しなけ ればならない。

ウイルス感染, 分化と成長, 発癌の際に, isoaccepting tRNA の存在比の変化, 既存の tRNA の修飾, 新 たな tRNA の合成など, tRNA の生物学的変動がしば しば認められるので, この tRNA の生物学的変動の意 義について考えるために，まず蛋白合成に括ける tRNA の役割についてふりか党ってみた.

tRNA は，アミノアシル tRNA 合成酵素によりアミ ノ酸を受容し，諸因子の助けにより，リボゾーム上で mRNA の code に応じたアミノ酸をペプチド鎖中に取 込ませる重要な役目を負っていることがわかった。 tRNA に存在すると思われるアミノ酸付着部位, アミノ アシル tRNA 合成酥素認識部位,リボジーム結合部位, 拈よび anticodon のどこかの部位が変われば，既存の 蛋白はつくられず，蛋白合成が止まるか，またはその新 たな tRNA に適した蛋白合成が始をるはずであるので, tRNA の生物学的変動の意義として蛋白合成の調節が 考兄られた。もちろん，蛋白合成の調節は tRNA だけ でなく，蛋白合成にたずさわる他の要素によってもコン トロールされている場合もあると思われる。

次に, tRNA の変動の化学的根拋を考光, 高次構造の 変換, アミノ酸付着末端の離合, メチル化, 酸化還元, イソペンテニル化，ヌクレアーゼによる分離など，既存 の tRNA の修飾とウイルスなどの新たな遺伝子の導入 による新たな tRNA の合成などを考吕た tRNA の変 動をカラムクロマトグラフィーで見つけた場合，常にそ
の変動の化学的根拋のどれに相当するかを調べる必要が ある.そこまで調べることによって，生物的現象を化学 の言葉で表わすことができる.

最後に，実際の個々の例について考光てみた，大腸菌 のトリプトファン tRNA について生物学的意味は不確 かであるが，かなりくわしくその変動のメカニズムを解 析した.このような化学的または物理化学的アプローチ は, 生物学的意味のはっきりした tRNA の変動をくわ しく調べる際の手本になると思われる，枯草菌のみなら ず他の生物系江括いても，カラムクロマトグラフィーに よって tRNA の変動を見つけながら, その化学的根拋 も掘り下げず, かつその生物学的意義も不明のままであ る報告が多かった．ウイルス感染系では，ウイルスによ り持込をれた遺伝子により新たな tRNA が合成され， このウイルス特異的 tRNA がウイルスのための蛋白合 成に関与するらしいことが示された。

バクテリアの mRNA は不安定であり，たえず新し いmRNA が合成されている。このような系では, 各 時期に合成される蛋白のための mRNA がその各時期 に合成されるのであるから，tRNA が同じでも各時期に 応じた蛋白がつくられるから，たとえ tRNA の変動に よる蛋白合成の調節があっても主流ではないと思われる.

それに対し, 多細胞系ではmRNA は安定であり, 後 期のための mRNA も初期存在する. このような系 では，tRNAをはじめ他の因子が各時期で異ならないと 同じ㔻白がつくられてしまう。ジミムシダマシにおいて 見つけられたごとく，主に tRNA の変動が蛋白合成を 調節している可能性が充分にある。

この意味からも, 癌化と tRNA の変動との関係は面 白く思われる．現在まではこの tRNA の変動が癌化の 原因なのか結果なのかも不明であるが，数年後に tRNA による癌化機構の題名で誰かにより総説の書かれること のできるときを期待して，この解説を終わる.

\section{文献}

1) P. Lengyel and D. Söll : Bacteriol. Rev., 33, 264(1969).

2) N. Sueoka and T. Sueoka : Progress in Nucleic Acid Research and Mol. Biol., 10, 23 (1970).

3) T. Ishida and N. Sueoka : Proc. Nat. Acad.Sci. U.S., 58, 1080 (1967)

4) W. J. Gartland, T. Ishida, N. Sueoka and M. W. Nirenberg: J. Mol. Biol., 44, 403 (1969).

5) T. Ishida and N. Sueoka: J. Biol. Chem., 243, 5329 (1968).

6) T. Ishida and N. Sueoka : J.Mol. Biol., 37, 313(1968).

7) T. Ishida and K. Miura : ibid., 11, 341 (1965). 